\title{
Generation of a heavy-mineral glacial indicator dispersal train from a diabase sill, Nipigon region, northwestern Ontario
}

\author{
Phillip Larson and Howard Mooers
}

\begin{abstract}
The heavy clinopyroxene mineral pigeonite forms a glacial indicator dispersal train originating from diabase intrusions in the Nipigon region of northwestern Ontario. Analysis and interpretation of the pigeonite dispersal pattern adjacent to the up-ice portion of the diabase provides a number of insights into the nature of glacial erosion of bedrock and the generation of heavy-mineral dispersal trains. Bedrock erosion and entrainment rates at the time of pigeonite dispersal train formation were high (3-14 $\left.\mathrm{mm} \cdot \mathrm{a}^{-1}\right)$, suggesting that bedrock erosion was rapid yet spatially and temporally restricted. Contrasting erosion rates between the diabase and surrounding greenstone lithologies suggests that modern shield topography is not an assemblage of equilibrium bedforms with respect to the ice sheet. This agrees with hypothesized low total erosion of shield bedrock during the Pleistocene. Pigeonite grain size coarsens over the diabase source, indicating that most of the pigeonite was quarried from outcrops as coarse diabase fragments. Down-ice of the diabase source the mean particle size of pigeonite recovered from till decreases, suggesting most of the pigeonite was liberated from bedrock by the comminution of coarse diabase clasts during glacial transport. While the conclusions drawn from this study may not necessarily apply to all heavy-mineral dispersal trains, the interpretive framework provides a foundation for comparative studies.
\end{abstract}

Résumé : Le minéral lourd de clinopyroxène, la pigeonite, sert de minéral indicateur d'un train glaciaire; elle provient des intrusions de diabase dans la région de Nipigon du nord-ouest de l'Ontario. L'analyse et l'interprétation du patron de dispersion de la pigeonite adjacente à la portion en amont glaciaire de la diabase fournissent plusieurs aperçus de la nature de l'érosion glacière du socle rocheux et la formation de trains glaciaires de minéraux lourds. Les taux d'érosion du socle rocheux et d'entraînement au moment de la formation du train de dispersion de la pigeonite étaient élevés (3-14 $\left.\mathrm{mm} \cdot \mathrm{a}^{-1}\right)$, suggérant une érosion rapide du socle rocheux bien que restreinte dans le temps et l'espace. En raison des taux d'érosion différents de la diabase et des lithologies environnantes de roches vertes, la topographie moderne du bouclier n'est pas un assemblage de formes du socle en équilibre par rapport au feuillet glaciaire. Cela concorde avec l'hypothèse d'une faible érosion totale du socle rocheux du bouclier au cours du Pléistocène. La granulométrie de la pigeonite devient plus grossière au-dessus de la source de diabase, indiquant que la plus grande partie de la pigeonite a été débitée des affleurements en fragments grossiers de diabase. En aval glaciaire de la source de la diabase, la dimension moyenne des particules de pigeonite récupérées d'un till décroît, suggérant que la plus grande partie de la pigeonite ait été libérée du socle rocheux par la comminution de clastes grossiers de diabase au cours du transport glaciaire. Alors que les conclusions tirées de cette étude ne s'appliquent pas nécessairement à tous les trains de dispersion des minéraux lourds, le cadre d'interprétation fournit une base pour des études comparatives.

[Traduit par la Rédaction]

\section{Introduction}

Identification and tracing of heavy-mineral glacial indicator dispersal trains is widely used as a mineral exploration tool in glaciated terrain (Peuraniemi 1990; McClenaghan et al. 2000). The method has proven to be of particular use in the search for diamondiferous kimberlites (McClenaghan and

Received 5 April 2004. Accepted 21 July 2005. Published on the NRC Research Press Web site at http://cjes.nrc.ca on 15 November 2005.

Paper handled by Associate Editor J.R. Desloges.

P. Larson ${ }^{1}$ and H. Mooers. Department of Geological Sciences, University of Minnesota, Duluth, MN 55812, USA.

${ }^{1}$ Corresponding author (e-mail: plarson2@d.umn.edu).
Kjarsgaard 2001), and it also has been successfully applied to exploration for gold and base metals (Averill 2001).

Despite the long and successful history of application of heavy-mineral indicator mineralogy and dispersal studies to mineral exploration, in many respects the processes and rates by which glaciers erode and entrain, transport, and deposit indicator minerals derived from a bedrock source are poorly understood. Consequently, subjecting heavy-mineral dispersal studies to rigorous quantitative analysis and interpretation remains problematic. Most analyses of indicator dispersal data are based on the empirical observation that indicator concentrations in till tend to decrease in a quasi-exponential fashion with increasing transport length from the indicator source (Gillberg 1965; Shilts 1976; Klassen 2001; Stea and Finck 2001).

Indicator dispersal data is typically interpreted using this empirical framework, and most surveys collect an initial, 
Fig. 1. Map of field area showing till sample locations. Shaded area is the diabase outcrop. Arrows indicate the regional ice flow direction reconstructed from striation orientations (this study; Thorleifson and Kristjansson 1993).

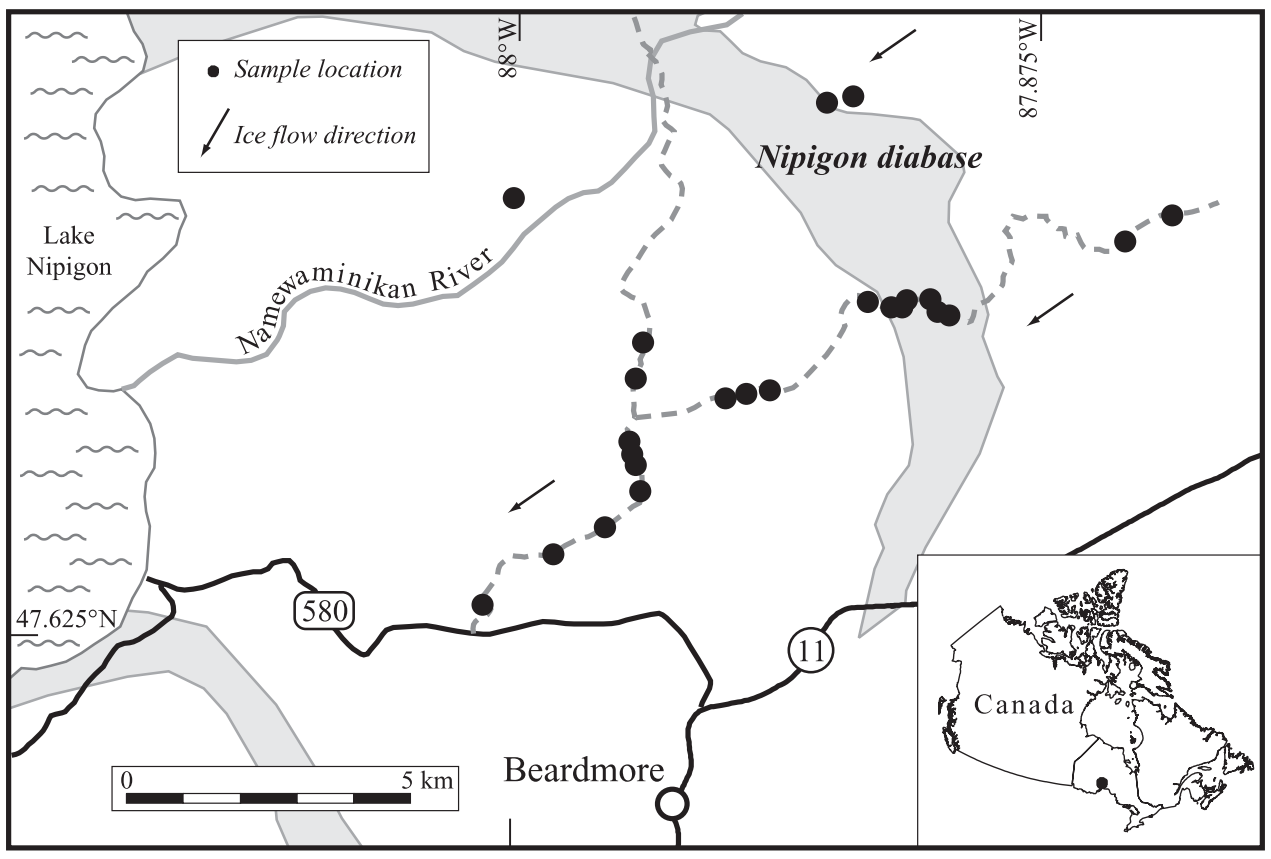

relatively large amount of data (samples) as a basis for interpretation. Development of a more rigorous quantitative framework promises to increase the amount of useful information derived from each till sample, allowing for a lower effective sampling density. Successful application will potentially decrease the expense associated with indicator mineral surveys and encourage their wider application. We propose to adapt a new conceptual model of indicator dispersal (Larson and Mooers 2004) to the interpretation of a heavy-mineral indicator dispersal train. Herein, the general relationships presented in Larson and Mooers (2004) are adapted to the problem of interpreting a particular heavy-mineral dispersal train in a particular geologic environment with minimal discussion of the conceptual model. Interested readers are referred to Larson and Mooers (2004) for a full discussion of the conceptual model.

\section{Study area}

During the course of a regional till heavy-mineral indicator survey, Bajc and Crabtree (2001) identified a large area southwest of Lake Nipigon, Ontario, in which tills yielded anomalous quantities of non-ferromagnetic heavy-mineral concentrates (NMHMC). Here, tills yield 300-400 g of NMHMC per $10 \mathrm{~kg}$ of till, compared to elsewhere on the Canadian Shield where yields of 40-50 g per $10 \mathrm{~kg}$ are more typical (Averill 2001). Most of this anomalous NMHMC is composed of the mineral pigeonite, which is a brown, dense (specific gravity of 3.3-3.4), Ca-poor clinopyroxene. The pigeonite, in turn, is derived from the Proterozoic Nipigon diabase, a series of laterally extensive sills underlying the Nipigon Embayment (Sutcliffe 1991).

The combination of a heavy mineral comprising a major rock-forming component and a well-defined source area make the pigeonite dispersal train an ideal tracer for examining and quantifying the processes by which glaciers generate heavy-mineral indicator dispersal trains. Our field area lies east of Lake Nipigon along the eastern (up-ice) contact of the Nipigon diabase (Fig. 1). Here, the easternmost outlier of the diabase is the westward-dipping sill intruding Archean metavolcanic and metasedimentary rock of the BeardmoreGeraldton greenstone belt. The map-view linear geometry of the sill, which happens to be oriented perpendicular to the ice-flow direction, allows investigation of both the incorporation of pigeonite into the glacial debris load and its evolution during transport without masking from additional pigeonite incorporation.

An examination of the up-ice portion of the Nipigon pigeonite dispersal train provides insight into the nature and rates of a number of glacial processes responsible for generation of heavy-mineral dispersal trains. These include (1) the rate of erosion and entrainment of the heavy- mineral indicator into the glacial debris load (i.e., how quickly the indicator dispersal train is resolvable from background values), (2) the particle-size distribution of eroded and entrained indicator material (i.e., if the indicator mineral is incorporated as monomineralic grains or within lithic fragments), and (3) the effect of comminution of the indicator during transport on the down-ice dispersal of the indicator dispersal plume (i.e. if comminution enhances or attenuates the heavy-mineral indicator signal).

\section{Bedrock geology}

The Nipigon diabase consists predominantly of olivine tholeiite diabase dikes and sills (Sutcliffe 1991). The diabase is associated with the Midcontinent Rift and was intruded at $\sim 1108 \mathrm{Ma}$. Major silicate mineral phases in the diabase include plagioclase, variable amounts of augite and pigeonite, olivine, minor orthopyroxene, magnetite, and biotite and micrographic quartz - alkali feldspar intergrowths (Mackasey 1975; Sutcliffe 1991). 
Table 1. Till sampling data.

\begin{tabular}{|c|c|c|c|c|c|c|c|}
\hline \multirow[b]{2}{*}{ Sample No. } & \multicolumn{2}{|c|}{ Sample locations } & \multirow[b]{2}{*}{ Substrate } & \multirow[b]{2}{*}{$\begin{array}{l}\text { Sample size } \\
(\mathrm{kg})\end{array}$} & \multirow[b]{2}{*}{$\begin{array}{l}T \text { from down-ice } \\
\text { contact }(\mathrm{m})\end{array}$} & \multirow[b]{2}{*}{$\begin{array}{l}T \text { from up-ice } \\
\text { contact }(\mathrm{m})\end{array}$} & \multirow[b]{2}{*}{$L(\mathrm{~m})$} \\
\hline & Latitude $\left({ }^{\circ} \mathrm{N}\right)$ & Longitude $\left({ }^{\circ} \mathrm{W}\right)$ & & & & & \\
\hline NIP-02 & 49.7114 & 87.9197 & Greenstone & 11.2 & -2040 & -413 & \\
\hline NIP-03 & 49.7101 & 87.9258 & Greenstone & 8.5 & -1615 & -42 & \\
\hline NIP-07 & 49.6723 & 87.9692 & Greenstone & 12.1 & 3473 & 6227 & 2754 \\
\hline NIP-08 & 49.6665 & 87.9710 & Greenstone & 9.9 & 3928 & 6810 & 2881 \\
\hline NIP-09 & 49.6931 & 87.8428 & Greenstone & 13.0 & -5585 & -3944 & \\
\hline NIP-10 & 49.6892 & 87.8539 & Greenstone & 9.6 & -4614 & -3006 & \\
\hline NIP-13 & 49.6773 & 87.8960 & Diabase & 11.1 & -859 & 690 & 690 \\
\hline NIP-14 & 49.6775 & 87.8985 & Diabase & 13.7 & -1027 & 854 & 854 \\
\hline NIP-15 & 49.6797 & 87.9008 & Diabase & 13.9 & -784 & 889 & 889 \\
\hline NIP-16 & 49.6793 & 87.9063 & Diabase & 12.1 & -406 & 1265 & 1265 \\
\hline NIP-17 & 49.6785 & 87.9073 & Diabase & 12.4 & -300 & 1371 & 1371 \\
\hline NIP-18 & 49.6782 & 87.9098 & Diabase & 13.3 & -116 & 1554 & 1554 \\
\hline NIP-20 & 49.6792 & 87.9156 & Greenstone & 9.1 & 208 & 1873 & 1665 \\
\hline NIP-21 & 49.6651 & 87.9388 & Greenstone & 12.3 & 2438 & 4108 & 1669 \\
\hline NIP-22 & 49.6645 & 87.9444 & Greenstone & 9.6 & 2830 & 4497 & 1667 \\
\hline NIP-23 & 49.6638 & 87.9494 & Greenstone & 10.1 & 3195 & 4860 & 1665 \\
\hline NIP-25 & 49.6935 & 88.0026 & Greenstone & 9.9 & 3241 & 4832 & 1591 \\
\hline NIP-26 & 49.6565 & 87.9725 & Greenstone & 11.5 & 4895 & 6746 & 1850 \\
\hline NIP-27 & 49.6532 & 87.9707 & Greenstone & 13.5 & 5123 & 6766 & 1745 \\
\hline NIP-28 & 49.6550 & 87.9718 & Greenstone & 10.2 & 5020 & 6788 & 1666 \\
\hline NIP-29 & 49.6489 & 87.9694 & Greenstone & 11.2 & 5255 & 6927 & 1671 \\
\hline NIP-30 & 49.6434 & 87.9778 & Greenstone & 12.2 & 6082 & 7756 & 1673 \\
\hline NIP-31 & 49.6388 & 87.9904 & Greenstone & 8.4 & 7136 & 8808 & 1672 \\
\hline NIP-33 & 49.6310 & 88.0069 & Greenstone & 6.1 & 8611 & 10284 & 1672 \\
\hline
\end{tabular}

Note: $T$, transport length; $L$, flowline outcrop thickness.

In the study area, the easternmost outlier of the Nipigon diabase consists of a westward-dipping 120-200 m thick sill (Mackasey 1975) (Fig. 1). The sill forms an east-facing scarp with up to $50 \mathrm{~m}$ of relief; locally, cliffs over $30 \mathrm{~m}$ high display columnar jointing.

The diabase sill intrudes a sequence of Archean metavolcanic and metasedimentary rocks (greenstone) (Mackasey 1975). In contrast to the diabase, these rocks are extensively metamorphosed, folded, and faulted. Abundant secondary mineral phases, such as chlorite and sericite, well-developed foliation, and local shearing result in a lithic assemblage that is significantly mechanically weaker than the younger diabase.

An indication of the relative strengths of the diabase and the greenstone country rock is provided by a comparison with engineering studies of similar rock types in northeastern Minnesota, USA. Unconfined compressive strengths (UCS) for the Silver Creek and Lafayette Bluff diabases ranged from 68 to $83 \mathrm{MPa}$ for weathered rock and from 99 to $248 \mathrm{MPa}$ for dense unweathered rock (CNA Consulting Engineers 1989, 1991). In comparison, the UCS of unweathered metavolcanic and metasedimentary rocks in the Soudan Mine ranged from 64 to $132 \mathrm{MPa}$ (CNA Consulting Engineers 1999).

\section{Glacial geology}

Thorleifson and Kristjansson (1993) described in detail the glacial geologic setting of the Beardmore-Geraldton region, including the study area. Till and other glacial sedi- ments in the study area are associated with the final retreat of the Laurentide ice sheet (LIS) at the end of the Wisconsinan glaciation. The probable time of till formation in the study area is bracketed by the minor readvance of the LIS to the Nipigon moraine to the west at about 9300 BP and a minor readvance of the LIS to the Nakina moraine to the east at about $8300 \mathrm{BP}$. As the ice retreated from the Nipigon moraine, topographically lower areas adjacent to Lake Nipigon in the western portion of the study area were inundated by Glacial Lake Kelvin (Zoltai 1965). Glacial Lake Kelvin was confluent with the Minong levels of Lake Superior and persisted from the retreat of the ice sheet from the Nipigon basin until 9000 BP.

In the study area, till occurs as a thin, discontinuous mantle overlying bedrock and is generally about $1 \mathrm{~m}$ thick. Striation orientations indicate a flow direction of $\sim 235^{\circ}$ during the last glaciation. In the western portion of the study area, the till is overlain by subaqueous outwash and glaciolacustrine silts and sands deposited in Glacial Lake Kelvin.

\section{Sampling and methods}

\section{Sampling}

Basal till samples were collected along a transect roughly parallel to the ice-flow direction over the diabase sill and up to $9 \mathrm{~km}$ down-ice. A total of 24 samples were collected: four from tills up-ice of the mapped extent of the diabase sill, six 
Table 2. Till granulometry.

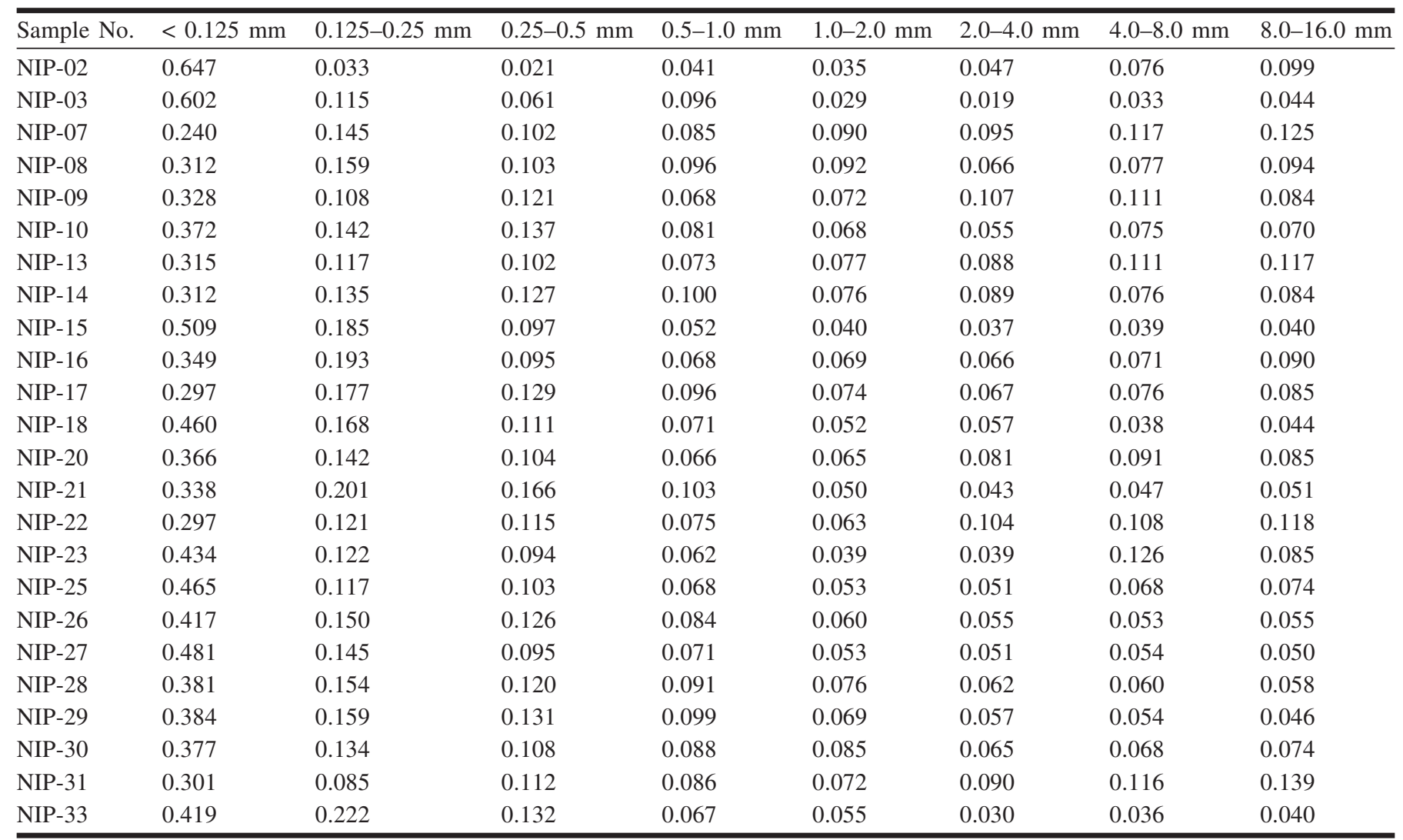

Note: Values are mass fraction of $<16 \mathrm{~mm}$ till particle-size fractions.

from tills directly overlying the sill, and 14 from tills downice of the sill (Fig. 1, Table 1).

Sample locations included road cuts and hand-dug pits. All samples were dense, semi-fissile lodgement tills collected from unweathered C-horizon material. Samples were collected as close to the bedrock surface as possible; most were collected from a depth of 0.5-1.0 m. Samples were screened in the field to remove clasts $>16 \mathrm{~mm}$. Mean till sample size was $11 \mathrm{~kg}$ (Table 1).

Transport lengths corresponding to each sample location were determined by measuring the distance in the flow direction from the down-ice edge of the diabase sill to the sample location (Table 1). The flowline outcrop thickness was similarly determined by measuring the distance between the up-ice and down-ice contacts of the diabase sill along a line extending from the sample location in the flow direction (Table 1). Bedrock contact locations were taken from Ontario Geological Survey (1993) bedrock mapping.

\section{Till granulometry}

Till particle-size distribution was determined by dry screening the $>2 \mathrm{~mm}$ fraction from the bulk sample. The relative proportions of the $>2 \mathrm{~mm}$ fractions were determined by further dry screening at $1 \phi$ intervals. The particle-size distribution of the $<2 \mathrm{~mm}$ fraction was determined by dry screening an $\sim 400 \mathrm{~g}$ split. Till particle-size distributions are summarized in Table 2.

\section{Heavy-mineral concentrate from till}

Heavy-mineral processing of the till samples was performed by Overburden Drilling Management Limited, Nepean, Ontario. The bulk samples were dried and weighed before screening to remove the $2-16 \mathrm{~mm}$ fraction; this material was retained to determine the concentration of coarse diabase clasts. The $<2 \mathrm{~mm}$ fraction was initially concentrated by wet-gravity tabling. The table concentrate was further concentrated to a $>3.2$ specific gravity, heavy-mineral concentrate (HMC) using density-dependent settling in methylene iodide diluted with acetone. Ferromagnetic minerals were separated from the HMC using an automagnet. The non-ferromagnetic fraction was dry-sieved at $0.125,0.25,0.5$, and $1.0 \mathrm{~mm}$. The mass fraction of NMHMC in each individual till particle-size fraction is summarized in Table 3.

One hundred-grain mineral counts were performed to establish the volume percentage of pigeonite for the 0.125 $0.25,0.25-0.5,0.5-1.0$, and $1.0-2.0 \mathrm{~mm}$ fractions of each sample (Table 4). The resulting volume percent of pigeonite is assumed to be equivalent to the mass percent.

\section{Pebble counts}

The concentration of diabase clasts in the $>2 \mathrm{~mm}$ fractions were determined by visually identifying and manually separating diabase clasts from splits comprising more than 500 grains from the $2-4,4-8$, and $8-16 \mathrm{~mm}$ fractions. The splits were weighed, and the mass concentration of diabase in each particle-size fraction calculated (Table 5).

\section{Heavy-mineral yield from diabase}

Four boulders of unweathered diabase were collected from outcrop and from till in the diabase dispersal train in the 
Table 3. Non-ferromagnetic heavy-mineral concentrate as a mass fraction of individual till particle-size fractions.

\begin{tabular}{llllllr}
\hline Sample No. & $<0.125 \mathrm{~mm}$ & $0.125-0.25 \mathrm{~mm}$ & $0.25-0.5 \mathrm{~mm}$ & $0.5-1.0 \mathrm{~mm}$ & $1.0-2.0 \mathrm{~mm}$ & Yield $\left(\mathrm{g} \cdot 10 \mathrm{~kg} \mathrm{~kg}^{-1}\right)$ \\
\hline NIP-02 & 0.004 & 0.010 & 0.007 & 0.002 & 0.002 & 38 \\
NIP-03 & 0.005 & 0.007 & 0.002 & 0.000 & 0.001 & 33 \\
NIP-07 & 0.009 & 0.015 & 0.016 & 0.016 & 0.009 & 101 \\
NIP-08 & 0.010 & 0.011 & 0.008 & 0.004 & 0.003 & 72 \\
NIP-09 & 0.008 & 0.019 & 0.008 & 0.006 & 0.004 & 102 \\
NIP-10 & 0.007 & 0.009 & 0.004 & 0.002 & 0.002 & 53 \\
NIP-13 & 0.010 & 0.018 & 0.012 & 0.012 & 0.009 & 116 \\
NIP-14 & 0.012 & 0.028 & 0.028 & 0.018 & 0.009 & 172 \\
NIP-15 & 0.009 & 0.015 & 0.018 & 0.027 & 0.019 & 117 \\
NIP-16 & 0.014 & 0.016 & 0.024 & 0.034 & 0.031 & 187 \\
NIP-17 & 0.014 & 0.018 & 0.016 & 0.017 & 0.018 & 154 \\
NIP-18 & 0.008 & 0.015 & 0.012 & 0.014 & 0.017 & 102 \\
NIP-20 & 0.017 & 0.029 & 0.027 & 0.033 & 0.027 & 215 \\
NIP-21 & 0.014 & 0.020 & 0.019 & 0.015 & 0.010 & 145 \\
NIP-22 & 0.010 & 0.021 & 0.015 & 0.019 & 0.024 & 158 \\
NIP-23 & 0.016 & 0.051 & 0.062 & 0.048 & 0.012 & 269 \\
NIP-25 & 0.013 & 0.031 & 0.022 & 0.022 & 0.019 & 156 \\
NIP-26 & 0.008 & 0.013 & 0.009 & 0.009 & 0.006 & 79 \\
NIP-27 & 0.004 & 0.008 & 0.009 & 0.008 & 0.006 & 54 \\
NIP-28 & 0.009 & 0.015 & 0.013 & 0.011 & 0.007 & 94 \\
NIP-29 & 0.009 & 0.014 & 0.009 & 0.006 & 0.005 & 85 \\
NIP-30 & 0.005 & 0.008 & 0.005 & 0.004 & 0.002 & 47 \\
NIP-31 & 0.003 & 0.010 & 0.006 & 0.004 & 0.002 & 43 \\
NIP-33 & 0.005 & 0.008 & 0.007 & 0.009 & 0.003 & 51 \\
\hline
\end{tabular}

study area in order to establish the recoverable NMHMC content of diabase. A portion of each boulder weighing $\sim 200 \mathrm{~g}$ was disaggregated to $<2 \mathrm{~mm}$ fragments by electric-pulse disaggregation (EPD) (Weiblen 1994; Saini-Eidukat and Weiblen 1996). The EPD tends to disaggregate rocks along grain boundaries among the constituent minerals, rather than across grains as with most mechanical crushing methods. In this respect, EPD closely reproduces the effects of glacial comminution, in which clasts tend to break along mineral grain boundaries and the final size distribution is dependent on the grain size of the parent rock (Haldorsen 1981).

The disaggregated diabase was dry sieved at $0.125,0.25$, 0.5 , and $1.0 \mathrm{~mm}$. A > 3.2 specific gravity HMC was separated from each of the resulting fractions using density-dependent settling in methylene iodide diluted with benzyl benzoate. Ferromagnetic minerals were separated from the HMC using a hand magnet.

The resulting NMHMC is composed almost entirely of pigeonite or pigeonite enclosing smaller plagioclase grains. The EPD NMHMC grains recovered from the boulders and pigeonite grains recovered from till are visually indistinguishable. The EPD NMHMC in the $0.125-2.0 \mathrm{~mm}$ particlesize fraction derived from comminution of diabase to $<2 \mathrm{~mm}$ comprises $42 \% \pm 8 \%$ of the original diabase mass. Using this factor, diabase concentrations in the $>2 \mathrm{~mm}$ clasts were converted to "pigeonite" concentrations. The mass fraction of pigeonite in each individual till particle-size fraction is summarized in Table 6. Henceforth, "pigeonite" refers to both pigeonite recovered from till in the 0.125 to $2.0 \mathrm{~mm}$ fractions and the inferred pigeonite concentration of diabase clasts in the 2.0 to $16.0 \mathrm{~mm}$ fractions.

\section{Results}

\section{Indicator dispersal train}

Pigeonite concentrations in till define an indicator dispersal train extending down-ice from the outcrop of the diabase sill (Fig. 2). The dispersal pattern displays a quasi-exponential decay with increasing transport length from source, which was empirically observed by Gillberg (1965) and many subsequent workers and predicted by Larson and Mooers (2004). The maximum concentration of pigeonite in till occurs near the down-ice edge of the indicator outcrop, suggesting that incorporated indicator material was rapidly mixed into a relatively thin basal debris layer.

Pigeonite concentrations in individual particle-size fractions in till generally mimic the quasi-exponential decay observed in the till as a whole (Fig. 3, Table 6). With the exception of the coarsest size fraction $(8.0-16.0 \mathrm{~mm})$, pigeonite concentrations increase rapidly over the diabase source and decrease with increasing transport length from the source.

\section{Erosivity}

Erosion and entrainment of bed material into the glacial debris load is quantified as erosivity represented by $E$ (unit of mass per cubic unit of length) (Larson and Mooers 2004). Erosivity describes the coupling between the glacier's bed and debris load, and it is the mass of bed material incorpo- 
Table 4. Volume percent pigeonite in non-ferromagnetic heavymineral concentrate.

\begin{tabular}{|c|c|c|c|c|}
\hline $\begin{array}{l}\text { Sample } \\
\text { No. }\end{array}$ & $0.125-0.25 \mathrm{~mm}$ & $0.25-0.5 \mathrm{~mm}$ & $0.5-1.0 \mathrm{~mm}$ & $1.0-2.0 \mathrm{~mm}$ \\
\hline NIP-02 & 2 & 0 & 0 & 1 \\
\hline NIP-03 & 1 & 0 & 0 & 0 \\
\hline NIP-07 & 17 & 55 & 66 & 77 \\
\hline NIP-08 & 9 & 32 & 45 & 39 \\
\hline NIP-09 & 3 & 4 & 3 & 3 \\
\hline NIP-10 & 2 & 0 & 1 & 1 \\
\hline NIP-13 & 25 & 45 & 50 & 63 \\
\hline NIP-14 & 50 & 58 & 78 & 73 \\
\hline NIP-15 & 28 & 47 & 78 & 72 \\
\hline NIP-16 & 36 & 52 & 76 & 74 \\
\hline NIP-17 & 39 & 50 & 69 & 72 \\
\hline NIP-18 & 16 & 35 & 36 & 40 \\
\hline NIP-20 & 43 & 54 & 59 & 65 \\
\hline NIP-21 & 45 & 67 & 58 & 33 \\
\hline NIP-22 & 43 & 61 & 66 & 72 \\
\hline NIP-23 & 71 & 84 & 92 & 79 \\
\hline NIP-25 & 57 & 68 & 83 & 75 \\
\hline NIP-26 & 33 & 43 & 54 & 25 \\
\hline NIP-27 & 24 & 37 & 43 & 38 \\
\hline NIP-28 & 47 & 64 & 52 & 30 \\
\hline NIP-29 & 16 & 47 & 43 & 27 \\
\hline NIP-30 & 7 & 13 & 7 & 3 \\
\hline NIP-31 & 24 & 19 & 22 & 12 \\
\hline NIP-33 & 10 & 52 & 54 & 39 \\
\hline
\end{tabular}

rated into the debris load per unit bed area per unit of length along the flowline. Over any flowline interval $T$, erosivity is related to an absolute erosion rate of $e$ (unit of length per unit of time) by

$$
\text { [1] } \quad E=\frac{e \rho_{b}}{u}
$$

where $\rho_{b}$ is the density of bed material and $u$ is the mean velocity of the basal debris load.

For tills along the flowline interval extending from the up-ice to the down-ice contacts of the diabase outcrop, erosivity is estimated by

$$
E=\frac{\left[\frac{m}{\left(1-c_{i}\right)}-m\right]}{L}
$$

where $c_{i}$ is the indicator (diabase) mass concentration, $L$ is the transport length from the up-ice diabase contact, and $m$ is the debris mass per unit bed area at the up-ice contact. Assuming $m$ was $1000 \mathrm{~kg} \cdot \mathrm{m}^{-2}$ at the up-ice contact (an amount of debris sufficient to produce a till layer $\sim 0.5 \mathrm{~m}$ thick upon deposition), erosivity values recorded in tills overlying the diabase average $0.028 \mathrm{~kg} \cdot \mathrm{m}^{-3}$ (Fig. 4A, Table 7).

Erosivity values for tills down-ice of the diabase outcrop are calculated by first estimating the mass of indicator material eroded and entrained per unit bed area $\left(m_{i}\right)$

[3] $m_{i}=E_{d} \cdot L$

where $E_{d}$ is the average erosivity estimate of $0.028 \mathrm{~kg} \cdot \mathrm{m}^{-3}$
Table 5. Diabase clasts as a mass fraction of 2-16 mm particle-size fractions.

\begin{tabular}{llll}
\hline Sample No. & $2-4 \mathrm{~mm}$ & $4-8 \mathrm{~mm}$ & $8-16 \mathrm{~mm}$ \\
\hline NIP-02 & 0 & 0 & 0 \\
NIP-03 & 0 & 0 & 0 \\
NIP-07 & 0.013 & 0.008 & 0.009 \\
NIP-08 & 0.028 & 0.007 & 0.018 \\
NIP-09 & 0 & 0 & 0 \\
NIP-10 & 0 & 0 & 0 \\
NIP-13 & 0.005 & 0.004 & 0.001 \\
NIP-14 & 0.162 & 0.036 & 0.013 \\
NIP-15 & 0.071 & 0.087 & 0.014 \\
NIP-16 & 0.053 & 0.023 & 0.016 \\
NIP-17 & 0.114 & 0.075 & 0.029 \\
NIP-18 & 0.058 & 0.035 & 0.010 \\
NIP-20 & 0.175 & 0.134 & 0.099 \\
NIP-21 & 0.066 & 0.036 & 0.042 \\
NIP-22 & 0.077 & 0.021 & 0.004 \\
NIP-23 & 0.423 & 0.767 & 0.645 \\
NIP-25 & 0.219 & 0.144 & 0.159 \\
NIP-26 & 0.023 & 0.018 & 0.017 \\
NIP-27 & 0.021 & 0.010 & 0 \\
NIP-28 & 0.023 & 0.009 & 0.003 \\
NIP-29 & 0.051 & 0.018 & 0 \\
NIP-30 & 0.001 & 0.001 & 0 \\
NIP-31 & 0.004 & 0.003 & 0.017 \\
NIP-33 & 0.005 & 0.009 & 0.013 \\
\hline
\end{tabular}

and $L$ in this case is the flowline length of the indicator outcrop. The resulting $m_{i}$ estimate is incorporated into the following equation to yield the erosivity values recorded in tills overlying the greenstone down-ice of the diabase

$$
E_{g}=\frac{\left(\frac{m_{i}}{c_{i}}-m_{i}-m\right)}{T}
$$

where $T$ is the transport length down-ice of the diabase outcrop. Using these assumptions, erosivity values recorded in tills overlying the greenstone average $0.854 \mathrm{~kg} \cdot \mathrm{m}^{-3}$ (Fig. 4A, Table 7).

The contrasting erosivity values recorded in tills overlying the diabase and the greenstone indicate that the ice sheet was able to erode and entrain weak, foliated, and fractured greenstone material at $\sim 31$ times the rate of hard, massive diabase (Fig. 4A).

\section{Erosion length scales}

Erosion length scale $(\lambda)$ (units of length) describes the influence of debris derived from up-ice on the magnitude and down-ice persistence of an indicator dispersal train (Larson and Mooers 2004). High values indicate that up-ice debris dominates the debris load, whereas low values indicate that locally derived indicator material is able to form dispersal trains with high signal to background contrast. Erosion length scales for tills overlying the diabase are calculated from 
Table 6. Pigeonite as a mass fraction of individual till particle-size fractions.

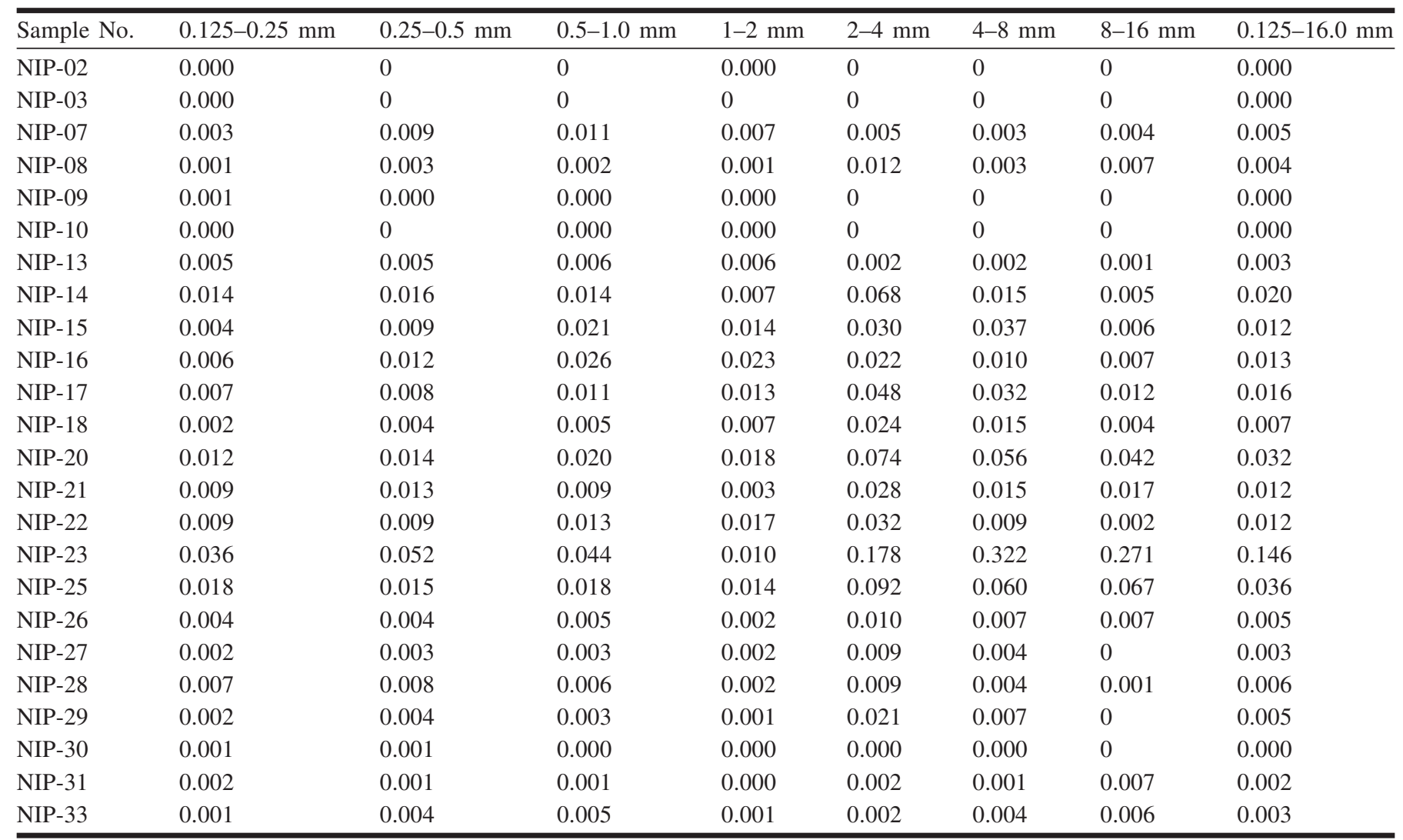

Note: Values are mass fraction of pigeonite in $0.125-16.0 \mathrm{~mm}$ particle-size fractions.

$$
\text { [5] } \lambda=\frac{m}{E_{d}}
$$

Assuming $m$ was $1000 \mathrm{~kg} \cdot \mathrm{m}^{-2}$ at the up-ice contact, and using the values for $E_{d}$ presented in Table 7, erosion length scales recorded in tills overlying the diabase average $49700 \mathrm{~m}$ (Fig. 4B, Table 7).

Erosion length scales for tills overlying the greenstone down-ice of the diabase outcrop are calculated with

[6] $\lambda=\frac{\left(m+m_{i}\right)}{E_{g}}$

Assuming $m$ was $1000 \mathrm{~kg} \cdot \mathrm{m}^{-2}$ at the up-ice contact, and using values for $E_{g}$ and $m_{i}$ presented in Table 7, erosion length scales recorded in tills overlying the greenstone average 2016 m (Fig. 4B, Table 7).

Calculated erosion length scales recorded in tills overlying the diabase outcrop are $\sim 25$ times higher relative to those of tills overlying down-ice greenstone. Similar to the erosivity values, this comparison indicates that greenstone was eroded and entrained at a significantly higher rate than diabase. Consequently, the down-ice propagation of the pigeonite indicator dispersal train is significantly retarded - more than it would have been if the greenstone were as strong as the diabase. Conversely, the maximum concentration of pigeonite in till at the down-ice contact of the diabase outcrop is significantly lower than it would have been if the diabase were as weak as the greenstone.

\section{Erosion rates}

A range of absolute erosion rates for both the diabase and the greenstone are calculated from the erosivity estimates using basal ice velocities of $10-50 \mathrm{~m} \cdot \mathrm{a}^{-1}$. This represents a range of basal velocities that are consistent with reasonable balance velocities near the margin of an ice sheet with a diameter of $900 \mathrm{~km}$ and characterized by a parabolic profile and uniform radial flow (see Paterson 1994). Diabase and greenstone densities were assumed to be 3000 and $2700 \mathrm{~kg} \cdot \mathrm{m}^{-3}$, respectively (eq. [1]). The apparent diabase erosion rate was $0.1-0.5 \mathrm{~mm} \cdot \mathrm{a}^{-1}$, whereas the greenstone erosion rate was $2.8-14.2 \mathrm{~mm} \cdot \mathrm{a}^{-1}$. The erosion rate calculated for the greenstone is comparable to the highest erosion rates estimated for modern large, temperate glaciers (Hallet et al. 1996).

The greenstone was apparently eroded at a rate $\sim 30$ times higher than the diabase. The disparate erosion rates of the two substrates, and the inverse correlation between erosion rate and substrate strength, suggest bed mechanical strength was the dominant control on erosion rates.

It is well established that LIS basal erosion rates varied both spatially and temporally over the course of a glacial cycle. Cold-based ice results in little, if any, erosion over significant areas in the interior of the ice sheet (Dyke 1993; Kleman 1994; Kleman and Bergstrom 1994). While at its maximum extent, expansion of cold-based ice towards the margin of the ice sheet insulates significant areas of the bed from erosion; these areas are subject to erosion during growth and decay of the ice sheet.

In addition, subglacial debris limits the spatial extent of 
Fig. 2. Pigeonite concentration in the $0.125-16 \mathrm{~mm}$ till particle-size fractions. Transport length is calculated along flowlines from the down-ice contact of the diabase outcrop. NIP-23 (0.146 pigeonite) not shown.

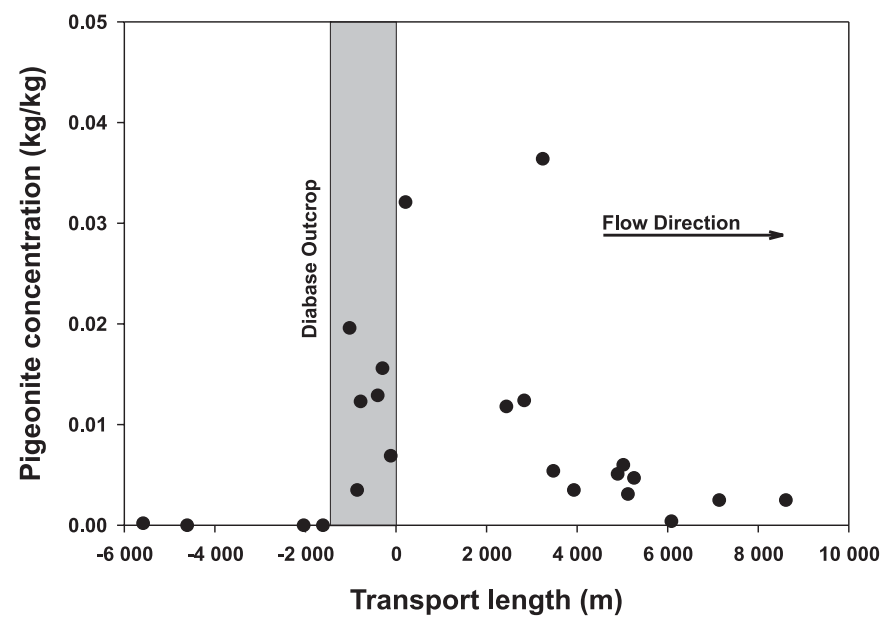

the bed subject to active erosion and entrainment; it also limits the duration of the erosion and entrainment. Debris deposited by earlier glacial cycles will insulate the underlying bedrock from glacial erosion during a later glacial cycle until the older debris is eroded and entrained. On a shorter time scale, deposition of subglacial debris early in a glacial cycle may insulate portions of the bed from erosion later in the glacial cycle.

Both cold-based ice and insulation by subglacial debris serve to restrict active glacial erosion at any given location on the bed of an ice sheet to some time period less than the entire length of the glacial cycle. Landscapes formed by glacial erosion therefore record only a portion of the history of a glacial cycle.

While not addressing the causes of spatial and temporal restriction of active erosion and entrainment processes beneath an ice sheet, the greenstone and diabase erosion rates estimated by this study can be used to quantify the extent of this restriction. The calculated erosion rates indicate that the relief of the diabase sill increased between 3 and 14 m per thousand years with respect to the surrounding landscape. Relief of the sill with respect to the surrounding landscape is only $50 \mathrm{~m}$ today, indicating $4000-18000$ years of active erosion at most during the Pleistocene.

Bedrock erosion and entrainment at such high rates would have resulted in enormous sediment fluxes to the margin. A conservative sediment flux estimate, assuming average erosivity values of $\sim 0.5 \mathrm{~kg} \cdot \mathrm{m}^{-3}$ over only $100 \mathrm{~km}$ of flowline length and a mean basal velocity of only $10 \mathrm{~m} \cdot \mathrm{a}^{-1}$, results in the delivery of 500 tonnes of debris per metre of width per year to the ice margin. Regionally, moraines deposited over the course of a few hundred years during the retreat of the LIS, such as the Nipigon moraine, may have been constructed by sediment fluxes of this order. However had erosion occurred at such rates over many hundreds of kilometres of flowline length, or if the mean basal velocity were higher, the correspondingly greater sediment flux would have constructed moraines significantly larger than those observed. Active erosion and entrainment of bedrock was thus probably restricted to on the order of $10-100 \mathrm{~km}$ of flowline length. The LIS advanced and retreated over hundreds of kilometres of scoured Canadian Shield bedrock landscape during the last glacial cycle. Therefore, apparently only a portion of the shield was subjected to active erosion and entrainment at any given time during the glacial cycle.

When subjected to active glacial erosion and entrainment during the Pleistocene, significant erosion of hard crystalline bedrock on this portion of the Canadian Shield apparently occurred at high rates comparable to those of modern temperate glaciers. However, such high erosion rates must have been restricted to a relatively small area of the bed of the ice sheet at any given time. The continuous scoured bedrock landscape observed on the Shield today is likely the cumulative product of localized bedrock erosion and entrainment processes acting successively over thousands of years of the last ice sheet's history.

\section{Pigeonite grain size}

The particle-size distribution of the pigeonite indicator is calculated from till granulometry (Table 2) and the mass fraction of pigeonite in individual till particle-size fractions (Table 6). Mean pigeonite grain size ranges from 0.34 to $8.69 \mathrm{~mm}$, with a mean of $2.18 \mathrm{~mm}$. The proportion of the pigeonite in individual till fractions from 0.125 to $16 \mathrm{~mm}$ is summarized in Table 8.

\section{Pigeonite over the diabase source}

The region overlying the diabase outcrop is the zone of erosion and entrainment of pigeonite into the glacial debris. Here, the mean particle size of pigeonite in the $0.125-16.0 \mathrm{~mm}$ till particle-size fraction increases across the diabase outcrop (Fig. 5). In general, one would expect the mean particle size of an indicator to stay constant or decrease with increasing degree of comminution during glacial transport. The changing particle size of an indicator due to glacial comminution is described by

$$
\frac{d x_{i}}{d T}=-k_{i} x_{i}+\sum_{j=1}^{i=1} a_{i j} k_{j} x_{j}
$$

where $x_{i}$ is the fraction of the indicator material in particlesize fraction ( $i), T$ is the transport length, and $k$ and $a_{i j}$ are constants that describe the rate of comminution and the particle-size distribution of comminution daughter products (Larson and Mooers 2004, adapted from Horst and Freeh 1970).

Inspection of eq. [7] indicates two scenarios that might result in an increase in $i$ : (1) particles in the size fraction $i$ break down at a higher rate than particles in size classes coarser than $i$, which would result in an apparent decrease in the amount of intermediate size particles relative to coarser and finer fractions; (2) if indicator material is added to the debris load in size fractions coarser than $i$, the breakdown of this material might add material to size fraction $i$ and result in an apparent coarsening of indicator material in that fraction.

With respect to scenario (1), fracture mechanics posits that fractures initiate at volume flaws within the clast (Lawn 1993). Such flaws in geologic materials may take the form of preexisting fractures, grain boundaries, or mineral cleavage planes. In general, the larger the flaw, the less energy required 
Fig. 3. Pigeonite concentrations in individual till particle-size fractions.

$0.125-0.25 \mathrm{~mm}$

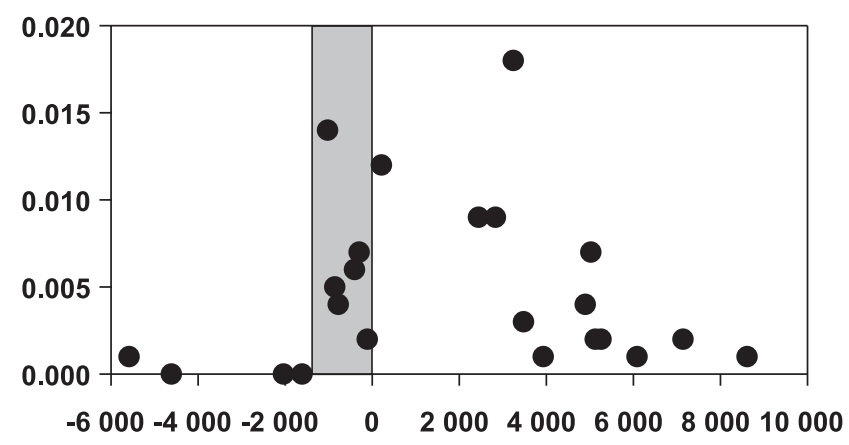

$0.5-1.0 \mathrm{~mm}$
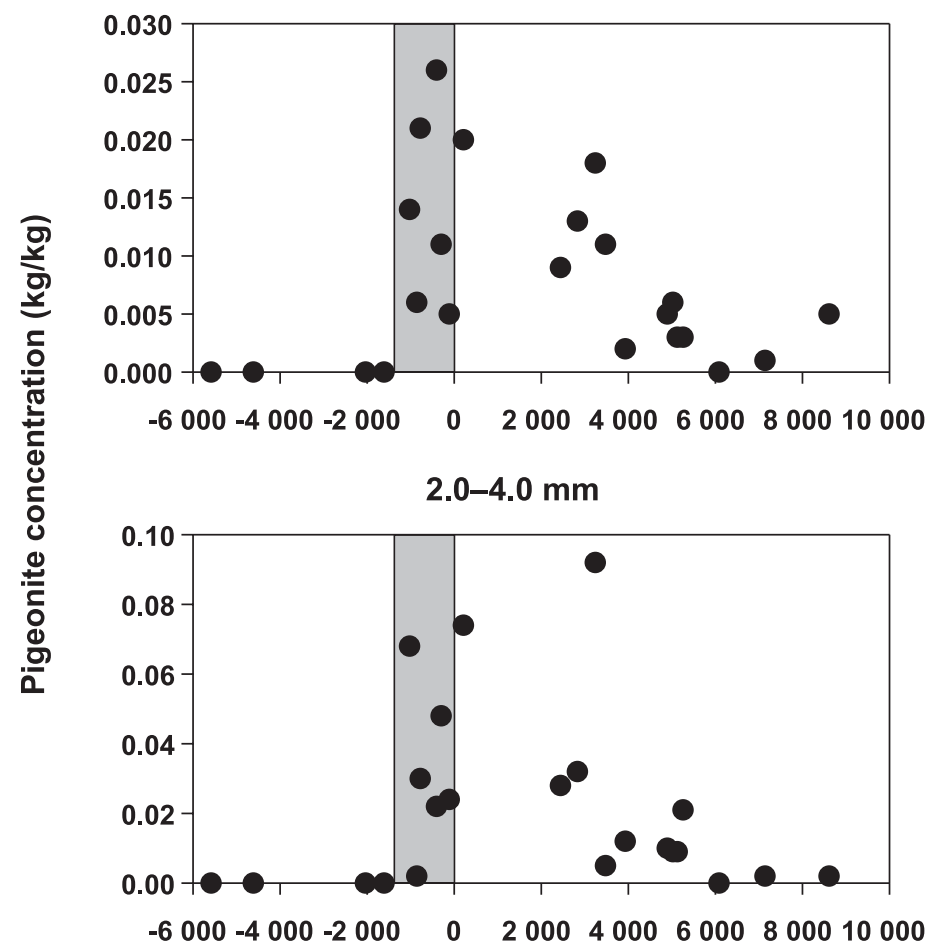

$0.25-0.5 \mathrm{~mm}$

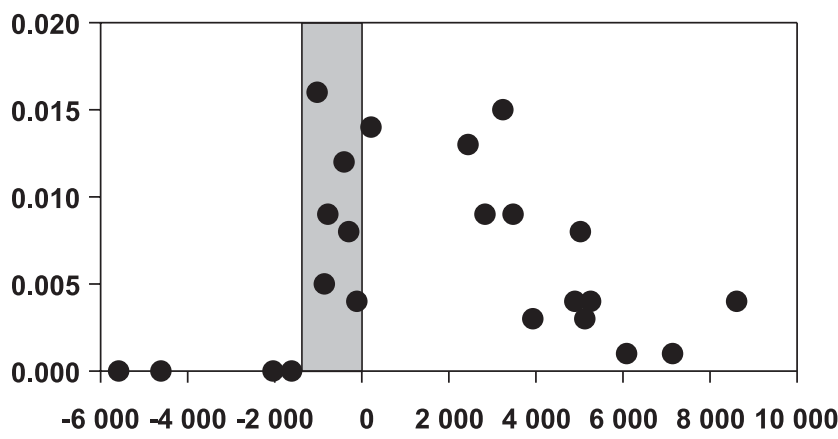

$1.0-2.0 \mathrm{~mm}$

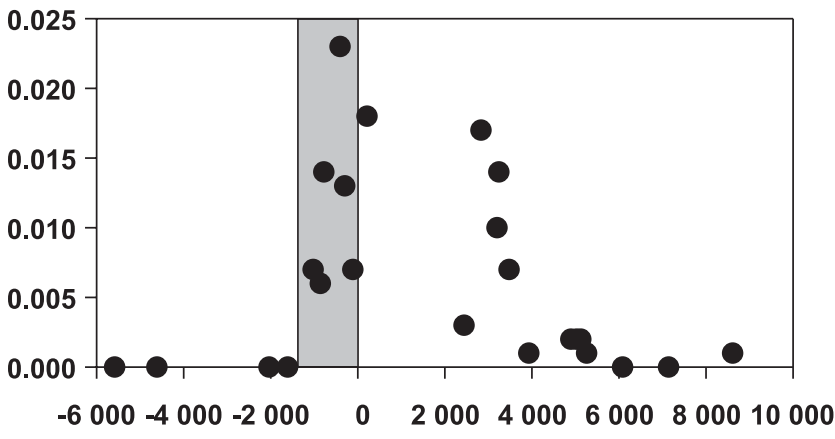

$4.0-8.0 \mathrm{~mm}$

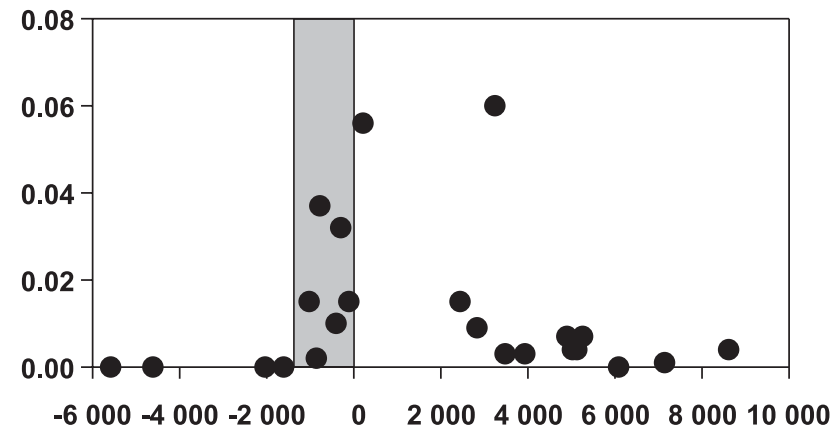

$8.0-16.0 \mathrm{~mm}$

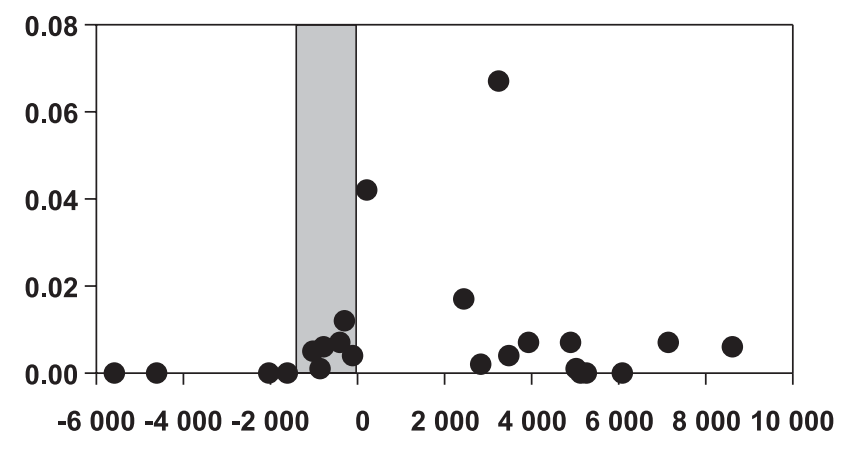

Transport length $(m)$

to propagate the fracture and result in breakage of the clast. During glacial comminution, coarser clasts might thus be expected to comminute at a higher rate than finer clasts
(Sharp and Gomez 1986). Therefore, scenario (1) is unlikely to have occurred.

With respect to scenario (2) and the pigeonite case in 
Fig. 4. Erosivity (A) and erosion length scale (B) values for tills overlying and down-ice of the diabase outcrop. Each data point represents a unique solution over the flowline, extending either from the up-ice or down-ice contact of the diabase outcrop. Note that, while erosivity and erosion length scale are inversely proportional, the exact relationship depends on the value selected for $m$, which is the amount of englacial debris per unit bed area. The absolute value of erosion length scale is independent of the estimate of $m$ and is the more robust parameter describing erosion and entrainment in a glacial system. Erosivity can be used to calculate an absolute erosion rate.

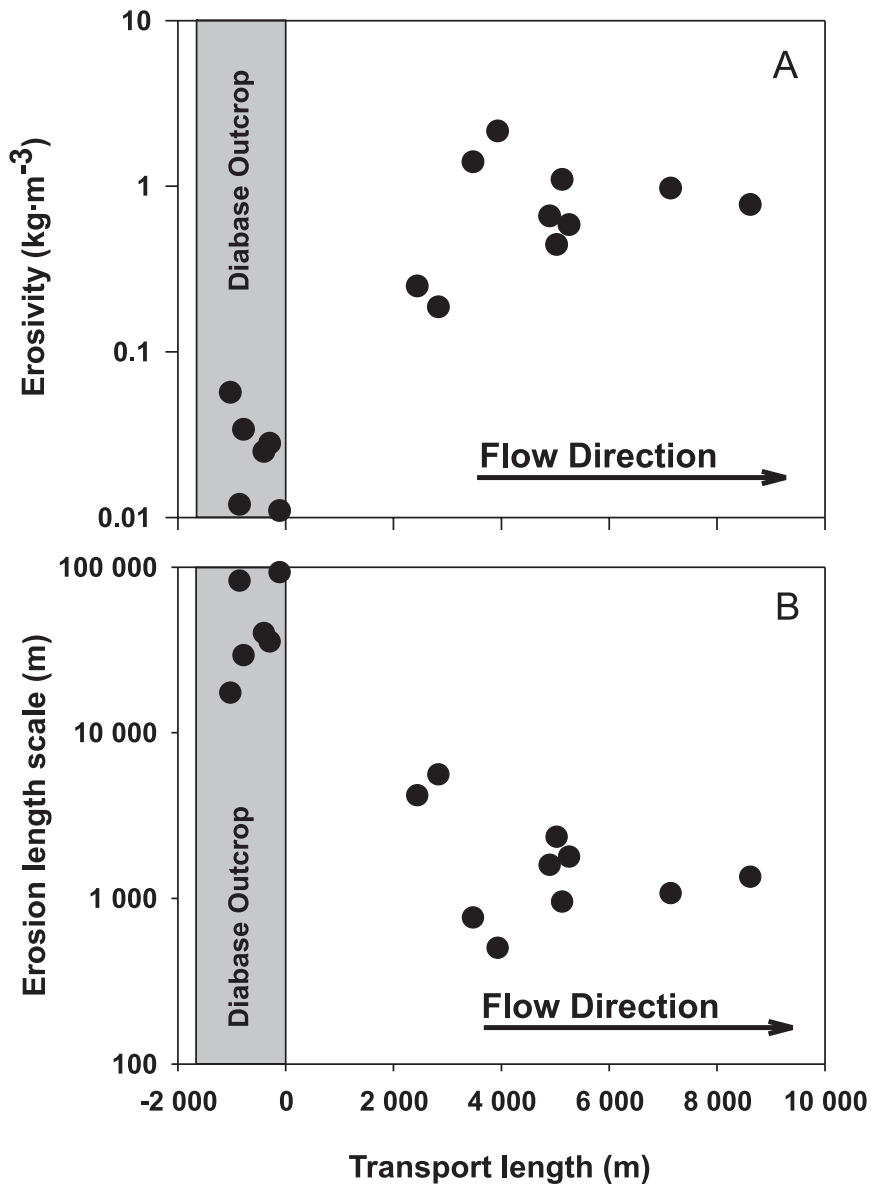

particular, the apparent increase in pigeonite grain size with transport length in tills overlying the diabase outcrop is probably indicative of incorporation of additional pigeonite as diabase clasts $>16 \mathrm{~mm}$. This, combined with the relative coarse mean size in this interval $(0.5-2.5 \mathrm{~mm})$ indicates that most of the erosion of diabase was taking place by the quarrying of larger lithic clasts rather than by the abrasion of smaller monomineralic clasts. Most of the pigeonite grains separated from till are the product of comminution of diabase clasts during transport and were not directly eroded from the outcrop.

\section{Pigeonite down-ice of the diabase source}

For transport lengths beyond the down-ice edge of the diabase outcrop, the mean pigeonite size decreases from $\sim 4$ to $\sim 0.5 \mathrm{~mm}$ over $9 \mathrm{~km}$ of glacial transport (Fig. 6). This is a consequence of both breakdown of the coarser diabase-
Table 7. Erosivity and erosion length scale estimates.

\begin{tabular}{llll}
\hline Sample & Substrate & $\begin{array}{l}E_{d} \text { erosivity } \\
\left(\mathrm{kg} \cdot \mathrm{m}^{-3}\right)\end{array}$ & $\begin{array}{l}\lambda \text { Erosion } \\
\text { length scale }(\mathrm{m})\end{array}$ \\
\hline No. & Diabase & 0.012 & 82724 \\
013 & Diabase & 0.057 & 17423 \\
015 & Diabase & 0.034 & 29345 \\
016 & Diabase & 0.025 & 39910 \\
017 & Diabase & 0.028 & 35561 \\
018 & Diabase & 0.011 & 93322 \\
007 & Greenstone & 1.405 & 767 \\
008 & Greenstone & 2.153 & 502 \\
020 & Greenstone & $*$ & \\
021 & Greenstone & 0.250 & 4184 \\
022 & Greenstone & 0.187 & 5604 \\
023 & Greenstone & $*$ & \\
025 & Greenstone & $*$ & \\
026 & Greenstone & 0.661 & 1592 \\
027 & Greenstone & 1.097 & 956 \\
028 & Greenstone & 0.445 & 2350 \\
029 & Greenstone & 0.586 & 1786 \\
030 & Greenstone & $*$ & 1074 \\
031 & Greenstone & 0.974 & 1348 \\
033 & Greenstone & 0.776 & 2016 \\
Average & Diabase & 0.028 & \\
Average & Greenstone & 0.854 & \\
\hline
\end{tabular}

Note: The estimated concentration of diabase at $\mathrm{T}=0$ for tills overlying the greenstone is calculated using the average erosivity value for tills overlying the diabase $\left(0.028 \mathrm{~kg} \cdot \mathrm{m}^{-3}\right)$. * indicates NIP-20, NIP-23, and NIP-25 are excluded from erosivity estimates because the diabase concentrations are higher than predicted. NIP-30 is excluded because it contains anomalously low diabase concentrations.

pigeonite clasts at a higher rate than the finer pigeonite clasts, and the lack of addition of new diabase-pigeonite to the debris load.

Theoretically, comminution of pigeonite grains proceeded until the grains reached the terminal grade (Dreimanis and Vagners 1971), likely fine sand. However, in as much as the samples collected for this study came from within $9 \mathrm{~km}$ of the source, it is likely that the bulk of the pigeonite was not comminuted to the terminal grade.

\section{Comminution enhancement of the pigeonite dispersal train}

Heavy-mineral indicator surveys commonly analyze indicator mineral concentrations in the $0.25-2.0 \mathrm{~mm}$ size fraction of till (Averill 2001; McClenaghan et al. 2000). The resulting concentration of indicator mineral in a restricted particle-size range is the dispersal concentration ( $c_{\text {DISP }}$ ) (Larson and Mooers 2004). In contrast, the concentration of indicator mineral in the entire till particle-size range is the dilution concentration $\left(c_{\text {DIL }}\right)$. Dispersal concentration is related to dilution concentration by

[8] $\quad c_{\text {DISP }}=\frac{c_{\text {DIL }} x_{i}}{x_{\text {till }}}$

where $x_{\text {till }}$ is the fraction of till in size fraction $i$.

In the case of the pigeonite dispersal train, the fraction of 
Table 8. Pigeonite granulometry.

\begin{tabular}{|c|c|c|c|c|c|c|c|c|c|}
\hline $\begin{array}{l}\text { Sample } \\
\text { No. }\end{array}$ & $0.125-0.25 \mathrm{~mm}$ & $0.25-0.5 \mathrm{~mm}$ & $0.5-1.0 \mathrm{~mm}$ & $1.0-2.0 \mathrm{~mm}$ & $2-4 \mathrm{~mm}$ & 4-8 mm & $8-16 \mathrm{~mm}$ & $0.25-2.0 \mathrm{~mm}$ & $\begin{array}{l}\text { Mean grain } \\
\text { size }(\mathrm{mm})\end{array}$ \\
\hline NIP-07 & 0.09 & 0.21 & 0.22 & 0.15 & 0.13 & 0.09 & 0.11 & 0.58 & 0.93 \\
\hline NIP-13 & 0.22 & 0.23 & 0.18 & 0.19 & 0.07 & 0.08 & 0.03 & 0.59 & 0.60 \\
\hline NIP-14 & 0.14 & 0.15 & 0.10 & 0.04 & 0.45 & 0.09 & 0.03 & 0.29 & 2.22 \\
\hline NIP-15 & 0.13 & 0.14 & 0.18 & 0.09 & 0.18 & 0.24 & 0.04 & 0.41 & 1.45 \\
\hline NIP-18 & 0.11 & 0.13 & 0.10 & 0.10 & 0.37 & 0.15 & 0.05 & 0.32 & 2.28 \\
\hline NIP-20 & 0.09 & 0.07 & 0.06 & 0.06 & 0.29 & 0.25 & 0.17 & 0.19 & 3.36 \\
\hline NIP-21 & 0.23 & 0.28 & 0.12 & 0.02 & 0.15 & 0.09 & 0.11 & 0.41 & 0.49 \\
\hline NIP-22 & 0.13 & 0.12 & 0.11 & 0.12 & 0.38 & 0.11 & 0.02 & 0.36 & 2.06 \\
\hline NIP-23 & 0.05 & 0.06 & 0.03 & 0.00 & 0.08 & 0.49 & 0.28 & 0.10 & 5.83 \\
\hline NIP-28 & 0.29 & 0.27 & 0.15 & 0.04 & 0.16 & 0.06 & 0.02 & 0.46 & 0.42 \\
\hline NIP-29 & 0.13 & 0.20 & 0.09 & 0.03 & 0.42 & 0.14 & 0.00 & 0.32 & 2.20 \\
\hline NIP-30 & 0.35 & 0.34 & 0.10 & 0.03 & 0.10 & 0.09 & 0.00 & 0.46 & 0.34 \\
\hline NIP-31 & 0.12 & 0.07 & 0.04 & 0.01 & 0.09 & 0.09 & 0.57 & 0.13 & 8.69 \\
\hline NIP-33 & 0.13 & 0.33 & 0.21 & 0.05 & 0.04 & 0.10 & 0.15 & 0.59 & 0.58 \\
\hline
\end{tabular}

Note: Values are mass fraction of pigeonite in $0.125-16.0 \mathrm{~mm}$ particle-size fractions.

Fig. 5. Mean particle size of pigeonite in the $0.125-16 \mathrm{~mm}$ till particle-size fractions overlying the diabase source. Linear regression line indicates an increase in mean particle size with increasing transport length from the up-ice contact $\left(r^{2}=0.36, p=0.03\right.$; both values are small because of clustering).

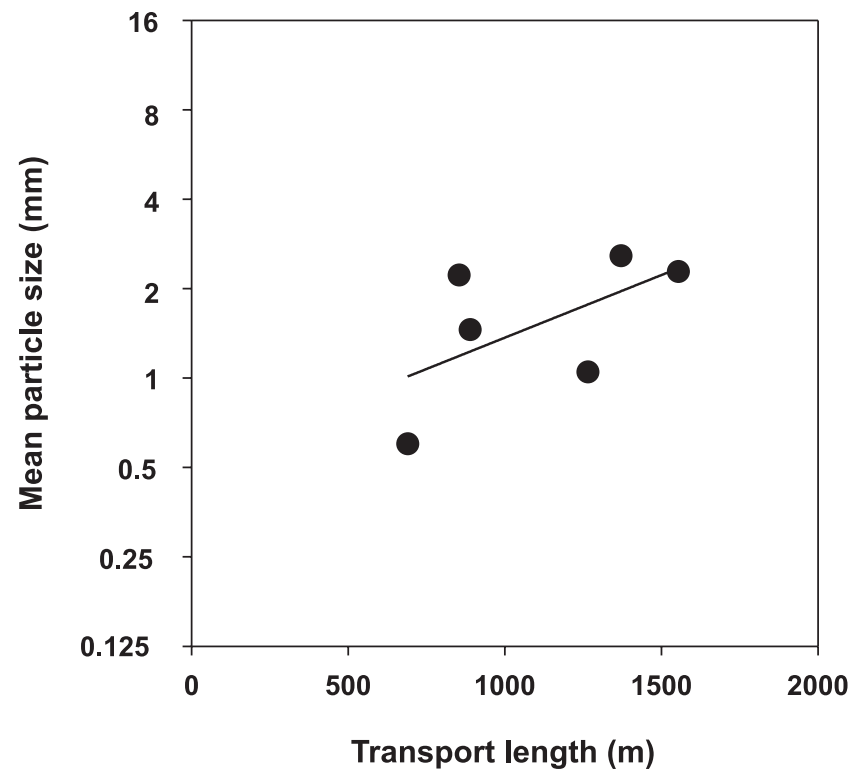

pigeonite in the $0.25-2.0 \mathrm{~mm}$ size fraction generally increases from $\sim 0.20$ at the down-ice contact of the diabase source to $\sim 0.45$ after $9 \mathrm{~km}$ of glacial transport. The fraction of till in the $0.25-2.0 \mathrm{~mm}$ size fraction stays roughly constant over the same transport interval.

The dispersal concentration of pigeonite in the $0.25-2.0 \mathrm{~mm}$
Fig. 6. Mean particle size of pigeonite in the $0.125-16 \mathrm{~mm}$ till particle-size fractions overlying and down-ice of the diabase source. A linear regression line indicates a decrease in mean particle size of $>2 \phi$ over $8 \mathrm{~km}$ of transport from the up-ice contact. Although the coefficient of determination is very low $\left(r^{2}=0.08, p=0.31\right)$, it is greatly influenced by a single value at $T=7136 \mathrm{~m}$.

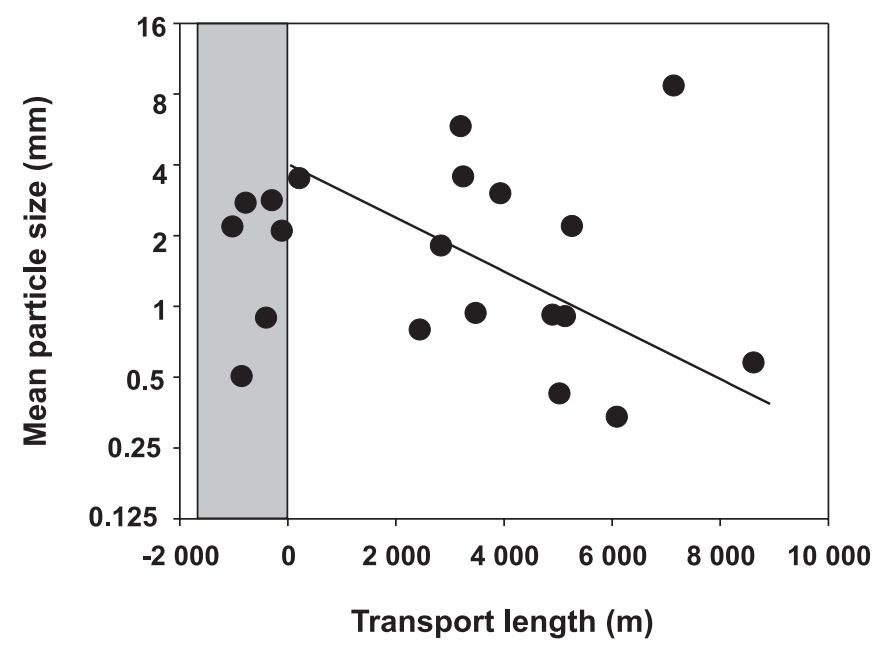

size fraction, if no comminution had taken place, can be estimated from eq. [8]. Assuming the pigeonite concentration in the $0.125-16.0 \mathrm{~mm}$ size fraction is that of the till (the dilution concentration), using the known $x_{\text {till }}$, and assuming a constant $x_{i}$ of 0.20 , the resulting calculated dispersal concentrations are only $40 \%$ of the values measured at the $9 \mathrm{~km}$ transport length. That is, at $9 \mathrm{~km}$ from the down-ice contact of the diabase, the actual pigeonite concentrations in the 
$0.25-2.0 \mathrm{~mm}$ till particle-size fraction are $\sim 250 \%$ higher than if no comminution taken place during transport.

\section{Conclusions}

Analysis and interpretation of a heavy-mineral indicator dispersal train using the conceptual model of indicator dispersal presented in Larson and Mooers (2004) provides a number of insights into the nature of bedrock erosion and entrainment by the LIS and the generation and down-ice propagation of indicator dispersal trains.

Erosivity and erosion length scale values calculated from indicator dispersal data indicate that the contrast in composition and mechanical strength between the indicator source and surrounding bedrock were reflected in the relative rates of erosion and entrainment. The inferred high erosion rates suggest that significant erosion of bedrock on the Canadian Shield was spatially and temporally restricted.

The inverse correlation between mechanical strength and erosion rates indicates that the bedrock topography is not an assemblage of equilibrium bedforms with respect to the ice sheet. The persistence of non-equilibrium landforms, despite multiple glaciations, supports the conclusions of Flint (1971), Gravenour (1975), Sugden (1976), and Kaszycki and Shilts (1987) that only a limited amount of bedrock erosion occurred on the Canadian Shield over the course of the Pleistocene. Bedrock landforms here and elsewhere on the shield likely reflect the geometry of the unweathered bedrock surface underlying a mantle of preglacial regolith (Feininger 1971; LidmarBergström 1997; Patterson and Boerboom 1998; Olvmo and Johansson 2002).

Analysis of the particle-size distribution of indicator material in the $0.125-16 \mathrm{~mm}$ till particle-size fraction suggests that erosion of the indicator source occurred predominantly by quarrying of coarse fragments of the indicator material. Therefore, most of the heavy-mineral indicators recovered from the dispersal train were released from the bedrock by the comminution of entrained rock fragments. Similarly, the contribution of heavy minerals liberated from comminuted rock fragments down-ice of the indicator source greatly increases the distance down-ice over which the heavy-mineral dispersal train can be detected and resolved from the background.

The conclusions drawn from investigation of the Nipigon pigeonite dispersal train are not necessarily directly applicable to analysis and interpretation of other heavy-mineral indicator dispersal trains, such as those related to gold mineralization or diamondiferous kimberlites. However, the conceptual framework presented in Larson and Mooers (2004) and used to quantify and interpret pigeonite dispersal in this study provides a basis for investigating, quantifying, and interpreting the erosion, entrainment, and transportation of indicator material in any glaciated region.

\section{Acknowledgments}

S. Averill and Overburden Drilling Management Ltd are gratefully acknowledged for providing heavy-mineral processing of the till samples gratis. P. Weiblen conducted the electric-pulse disaggregation of diabase boulders. The University of Minnesota Graduate School provided financial support for this study. Thoughtful reviews by $\mathrm{H}$. Thorleifson, R. DiLabio, and J. Desloges (Associater Editor) are gratefully acknowledged.

\section{References}

Averill, S.A. 2001. The application of heavy indicator mineralogy in mineral exploration with emphasis on base metal indicators in glaciated metamorphic and plutonic terrain. In Drift exploration in glaciated terrain. Edited by M.B. McClenaghan, P.T. Bobrowsky, G.E.M. Hall, and S.J. Cook. Geological Society (of London), Special Publication 185, pp. 69-81.

Bajc, A.F., and Crabtree, D.C. 2001. Results of regional till sampling for kimberlite and base metal indicator minerals, Shebandowan greenstone belt, northwestern Ontario. Ontario Geological Survey, Open File Report 6046.

CNA Consulting Engineers. 1989. Lafayette Bluff Tunnel geotechnical report. Prepared for the Minnesota Department of Transportation, State Project No. 3805-58 (T.H. 61).

CNA Consulting Engineers. 1991. Silver Cliff realignment geotechnical report. Prepared for the Minnesota Department of Transportation, State Project No. 3805-55 (T.H. 61).

CNA Consulting Engineers. 1999. MINOS far detector laboratory site and geotechnical data report. Prepared for the University of Minnesota, UM Project No. 896-95-1634.

Dreimanis, A., and Vagners, U.J. 1971. Bimodal distribution of rock and mineral fragments in basal tills. In Till - a symposium. Edited by R.P. Goldthwait. Ohio State University Press, Columbus, Ohio, pp. 237-250.

Dyke, A.S. 1993. Landscapes of cold-centred Late Wisconsinan ice caps, Arctic Canada. Progress in Physical Geography, 17: 223-247.

Feininger, T. 1971. Chemical weathering and glacial erosion of crystalline rocks and the origin of till. U.S. Geological Survey Professional Paper 750-C, pp. C65-C81.

Flint, R.F. 1971. Glacial and quaternary geology. Wiley Press, New York.

Gillberg, G. 1965. Till distribution and ice movements on the northern slopes of the south Swedish highlands. Geologiska Förenings i Stockholm Förhandlingar, 86: 433-484.

Gravenour, C.P. 1975. Erosion by continental ice sheets. American Journal of Science, 275: 594-604.

Haldorsen, S. 1981. Grain-size distribution of subglacial till and its relation to subglacial crushing and abrasion. Boreas, 10: 91-105.

Hallet, B., Hunter, L., and Bogen, J. 1996. Rates of erosion and sediment evacuation by glaciers: A review of field data and their implications. Global and Planetary Change, 12: 213-235.

Horst, W.E., and Freeh, E.J. 1970. Mathematical modeling applied to analysis and control of grinding circuits, Part 1: Development of comminution models. Society for Mining Metallurgy and Exploration of the American Institute of Mining, Metallurgical, and Petroleum Engineers. Preprint 70-B-27.

Kaszycki, C.A., and Shilts, W.W. 1987. Glacial erosion of the Canadian Shield. In Geomorphic systems of North America. Edited by W.L. Graf. Geological Society of America (GSA), Centenary Vol. 2, pp. 155-161.

Klassen, R.A. 2001. A Quaternary perspective on geochemical exploration in glaciated terrain. In Drift exploration in glaciated terrain. Edited by M.B. McClenaghan, P.T. Bobrowsky, G.E.M. Hall, and S.J. Cook. Geological Society (of London), Special Publication 185, pp. 1-17.

Kleman, J. 1994. Preservation of landforms under ice sheets and ice caps. Geomorphology, 9: 19-32.

Kleman, J., and Bergstrom, I. 1994. Glacial land forms indicative of a partly frozen bed. Journal of Glaciology, 40: 255-264. 
Larson, P.C., and Mooers, H.D. 2004. Glacial indicator dispersal processes: a conceptual model. Boreas, 33: 238-249.

Lawn, B. 1993. Fracture of brittle solids. 2nd ed. Cambridge University Press, Cambridge, UK.

Lidmar-Bergström, K. 1997. A long-term perspective on glacial erosion. Earth Surface Processes and Landforms, 22: 297-306.

Mackasey, W.O. 1975. Geology of Dorothea, Sandra, and Irwin Townships, District of Thunder Bay. Ontario Division of Mines, Geological Report 122.

McClenaghan, M.B., and Kjarsgaard, B.A. 2001. Indicator mineral and geochemical methods for diamond exploration in glaciated terrain in Canada. In Drift exploration in glaciated terrain. Edited by M.B. McClenaghan, P.T. Bobrowsky, G.E.M. Hall, and S.J. Cook. Geological Society (of London), Special Publication 185, pp. 83-123.

McClenaghan, M.B., Thorleifson, L.H., and DiLabio, R.N.W. 2000. Till geochemical and indicator mineral methods in mineral exploration. Ore Geology Reviews, 16: 145-166.

Olvmo, M., and Johansson, M. 2002. The significance of rock structure, lithology and pre-glacial weathering for the shape of intermediate-scale glacial erosional landforms. Earth Surface Processes and Landforms, 27: 251-268.

Ontario Geological Survey. 1993. Bedrock geology, seamless coverage of the province of Ontario. Ontario Geological Survey, ERLIS Data Set 6.

Paterson, W.S.B. 1994. Physics of glaciers. Pergamon Press, Tarrytown, N.Y.

Patterson, C.J., and Boerboom, T.J. 1998. The significance of preexisting, deeply weathered crystalline rock in interpreting the effects of glaciation in the Minnesota River valley, U.S.A. Annals of Glaciology, 28: 53-58.
Peuraniemi, V. 1990. Heavy minerals in glacial material. In Glacial indicator tracing. Edited by R. Kujansuu and M. Saarnisto. A.A. Balkema, Rotterdam, The Netherlands, pp. 165-185.

Saini-Eidukat, B., and Weiblen, P.W. 1996. A new method of fossil preparation, using high-voltage electric pulses. Curator, 39: 139-144.

Sharp, M.P., and Gomez, B. 1986. Processes of debris comminution in the glacial environment and implications for quartz sand-grain micromorphology. Sedimentary Geology, 46: 33-47.

Shilts, W.W. 1976. Glacial till and mineral exploration. In Glacial till: an interdisciplinary study. Edited by R.F. Legget. Royal Society of Canada, Special Publication 12, pp. 204-225.

Stea, R.R., and Finck, P.W. 2001. An evolutionary model of glacial drift dispersal and till genesis in Maritime Canada. In Drift exploration in glaciated terrain. Edited by M.B. McClenaghan, P.T. Bobrowsky, G.E.M. Hall, and S.J. Cook. Geological Society (of London), Special Publication 185, pp. 236-265.

Sugden, D.E. 1976. A case against deep erosion of shields by ice sheets. Geology, 4: 580-582.

Sutcliffe, R.H. 1991. Proterozoic geology of the Lake Superior area. In Geology of Ontario. Edited by P.C. Thurston, H.R. Williams, R.H. Sutcliffe, and G.M. Stott. Ontario Geological Survey, Special Vol. 4, Part 1, pp. 627-658.

Thorleifson, L.H., and Kristjansson, F.J. 1993. Quaternary geology and drift prospecting, Beardmore-Geraldton area, Ontario. Geological Survey of Canada, Memoir 435.

Weiblen, P.W. 1994. A novel electric pulse method for obtaining clean mineral separates for geochemical and geophysical research. EOS, Transactions of the American Geophysical Union, 75: 70.

Zoltai, S.C. 1965. Glacial features of the Quetico-Nipigon area, Ontario. Canadian Journal of Earth Sciences, 2: 247-269. 